\title{
Transitioning from University to Working Life: A Comparison of Business Graduates' Perceptions of Skills before and during the COVID-19 Pandemic
}

\author{
Elisa Gagnon \\ Bishop's University \\ elisa.gagnon@ubishops.ca
}

\begin{abstract}
The COVID-19 pandemic has disrupted business schools and students. The unusual circumstances created by the pandemic situation have provided a unique occasion to look at challenges and opportunities facing business graduate students when transitioning from university to working life. Using a survey from business students who graduated before and during the COVID-19 pandemic, this study explores the role of skills (IT and non-IT skills) in the transition from university to working life as well as the impact of the COVID-19 pandemic on business students' skills and career decisions. It was found that non-IT skills were perceived as more essential than IT skills, and having IT skills such as data analytics and business applications of Artificial Intelligence (AI) were more essential skills for students who graduated during the pandemic. Finally, business students who have been impacted by the COVID-19 pandemic are considering acquiring new digital/technological skills.
\end{abstract}

\section{Introduction}

The relationship between the skills and competencies possessed by university graduates and the job market has been the focus of growing theoretical and empirical investigations in the education literature [1]. Employability assumes specific types of skills and competencies and employers expect that upon working, graduates will be equipped with the necessary skills [2]. Identification of employability skills has also be used as a developmental tool to enable students to engage with the concept of employability in terms of their strengths and weaknesses [3].

However, the employment situation has been changed by the COVID-19 pandemic, disturbing businesses and accelerating the transition to a digital economy. For example, millions of people lost their job, social distancing has created the revision of work standards in many industries, and the conditions of employment have changed. Indeed, organizations have been affected by mandatory telework and Information Technology (IT) competencies and skills have been affected by this shift $[4,5]$. Additionally, IT has played an important role in the shift in current and future training, and digital competencies are considered an essential element of graduate students [6]. Indeed, the need for digital, mobile communication and IT skills and competencies has been impacting graduate students entering the workforce [7]. It could therefore be expected that business students graduating after the COVID-19 pandemic will need to have a broader understanding of the digital environment and adjust to remote working or more flexible working arrangements [4]. Business graduates are thus likely to look at ways to become more employable as employment prospects in the future are perceived as low with the COVID-19 pandemic $[8,9,10]$.

However, there is a limited understanding of how the COVID-19 pandemic has impacted the necessary skills of business students to transition to working life and their future employment situation. The purpose of this study is to conduct an empirical assessment using survey methodology of business graduates' skills to transition from university to working life in the context of the COVID-19 pandemic. Specifically, this study intends to: (1) understand the graduate employability of business students in terms of IT and non-IT skills, (2) identify the impact of the COVID-19 pandemic situation on the differences regarding the above skills before and during the COVID-19 pandemic, and (3) recognize the impact of the COVID-19 pandemic on business students' adaptation to their future working life in terms of jobs search, salary, area of work, graduate school, and IT skills. There is an expectation that business graduates be proficient in terms of various non-IT and IT skills. Therefore, questions related to the level of skills are important to employers and post-secondary institutions, especially during disturbing periods such as the COVID-19 pandemic [11].

The rest of the paper is organized as follows. First, the literature on skills for business graduates and the 
impact of the COVID-19 pandemic on students in higher education is described as well as assumptions are provided. Then, the method used to collect the data is presented. Findings and discussions are presented next. Finally, the paper concludes with implications for research and education, limitations, and future research.

\section{Background and Hypotheses}

\subsection{Overview of the current research on IT and non-IT skills for business graduates}

Education is not all about attaining good marks but it is also about exploring and developing skills and competencies for preparing for the workplace. Business schools are tasked with training the next generation of managers. Furthermore, the growing omnipresence of IT in businesses and the constantly evolving IT landscape have altered the nature of job structures and business activities and transformed the way businesses make decisions [12, 13]. As a consequence, there is a surge in demand for advanced IT skills among university graduates and even more for business graduates [14, 15]. Indeed, it was found that fluency with information technology was an important skill needed in the workforce for all university students [14] and an essential skill for the employment of library science students [16].

A large body of studies on IT skills for business graduates has investigated the advanced IT skills needed for accounting graduates $[6,17,18,19,20]$ such as business analytics, IT forensic, enterprise systems, spreadsheet, and business process analysis. Marketing graduates should also be able to utilize data and statistics to analyze an organization's marketing environment and the performance of a marketing strategy [21]. Graduates of management information systems (MIS) degrees are expected to be knowledgeable on a selection of hardware and software and be able to develop new applications [15, 22, 23]. Graduates of programs in Enterprise Resource Planning (ERP) are expected to have technical skills in ERP and technology management as well as non-IT skills such as business functional, interpersonal, and team skills [24]. The need for digital competencies, data analytics, and office softwares was also found to be important for business graduates [12, 13, 25, 26]. Finally, results also showed the importance of contextualizing IT skills to the needs of business workplaces [13].

Thus, previous research suggests that employers expect graduates to have sufficient and appropriate IT skills, which are fundamental in data-rich business settings for all business graduates. Even though we can assume that current business students have a sufficient understanding of IT in general, they lack advanced skills. Indeed, business schools have incorporated technologies, such as data visualization software, enterprise systems, and data analytics into various business program areas such as accounting and marketing, and have redesigned their curriculum to include a variety of advanced IT skills [25]. Consequently, IT skills are crucially important for business graduates in all fields and represent a significant element that is demanded by employers [12].

Finally, there is considerable literature dedicated to investigating the non-IT skills of accounting [27], business [28, 29], and information systems (IS) [30] graduates in a variety of industries and countries [31]. Non-technical skills are those cognitive and soft skills such as communication, problem-solving, personal ethics, etc., required to successfully apply disciplinary knowledge in the workplace [28]. For example, it was found that skills in the non-technical categories to be more important to MIS career success than those in technical categories [32], and the combination of both IT and non-IT skills will continue to be needed [33]. Interestingly, IS programs are focusing on integrating non-IT skills to make sure that students are graduating with well-developed ones. Similarly, from the employers' perspectives, importance of soft skills was found to be important when recruiting business graduates [29]. Finally, studies on the employers' views of how well university graduates are prepared for the workplace as well as the alignment between university graduate attributes and accreditation requirements have been widely explored [20, 31, 34, 35, 36]. Therefore, the first hypothesis states that:

Hypothesis 1: Non-IT skills are expected to be more essential than IT skills for business graduate students.

\subsection{Influence of the COVID-19 pandemic on students}

The COVID-19 pandemic is producing unprecedented global disruptions. However, the impact of the COVID-pandemic on our society and business graduates is still unknown. A small number of empirical studies have looked at how the pandemic has influenced students in higher education. For example, a recent study looking at hard and soft skills before and during the COVID-19 pandemic has found differences among critical skills needed for graduate employability in sport management [37]. For instance, consumer psychology, financing, and international experiences were rated as significantly different between before and during the COVID-19 pandemic.

Similarly, international students and courses that had an experiential nature such as entrepreneurship education have also been negatively impacted by the COVID-19 pandemic[38, 39]. It was also revealed that 
work and internship experiences would add extra value to graduate employability as well as soft skills for accounting graduates during the COVID-19 pandemic [10]. Indeed, students who have completed a remote internship during the COVID-19 pandemic have experienced working conditions that will shape positively their professional future by closely reflecting the future office working conditions [4]. Finally, it was found that business students have been affected by the context of the COVID-19 pandemic in acquiring professional skills, suggesting that students are missing important skills after graduating [40].

Hypothesis 2: The importance of skills (IT and nonIT skills) perceived as essential by business students has been affected by the COVID-19 pandemic.

Similarly, the COVID-19 pandemic has created significant challenges for the higher education community and forced changes for business students and faculty members at a scale that was not seen before. For instance, the nature of entrepreneurship education is likely to change because of the COVID-19 pandemic $[38,39]$. This event coincides with the increase in the importance of IT skills due to the increased usage of disruptive technologies such as artificial intelligence (AI), big data, and automation. Technology plays a key role in this due to the need for digital learning environments [39]. The result will influence the importance of IT skills for business graduates during and after a disrupting time. This leads to the third hypothesis:

Hypothesis 3: The IT skills should gain more importance because of the COVID-19 pandemic context.

Finally, the COVID-19 pandemic has had impacts on students for future employment and career decisions. Without question, the COVID-19 outbreak had large negative effects on students' current labor market participation and expectations. For example, previous studies have observed that students have delayed graduation, lost a job or job offer, changed their job search behavior, and are expected to earn less at age 35 because of the COVID-19 pandemic [9, 42, 43]. Furthermore, it was found that household income, gender, ethnicity, and first-generation college status of students have different impacts on their digital barriers in distance education [41]. The lives of students have also been changed by the need to learn new technologies and shift to virtual learning [42, 44].

Hypothesis 4: The COVID-19 pandemic context has impacted business students' career decisions and outcomes.

\section{Methods}

The underlying data used for this study was collected by a survey sent during two time periods using a standardized online questionnaire (Limesurvey). The survey was first designed based on a review of the literature on skills and competencies for business students $[6,35]$. Second, a panel of six experts tested and reviewed the survey to help with clarity and confirm the skills selected. Finally, three rounds of revisions were made based on the feedback.

The study involved e-mailing a cover letter and a link to the survey. Respondents who completed the survey were eligible to win a $\$ 50$ Amazon gift card (5 cards for the $1^{\text {st }}$ sample and 2 cards for the $2^{\text {nd }}$ sample).

The two samples consisted of recent business graduates who had finished business degrees. For the first sample, the survey was conducted in February 2020 and sent to 736 undergraduate business students who graduated from a small liberal arts university in Canada from 2016 to 2019 (May). The second time, the survey was conducted in April 2021 and sent to 148 students who graduated in 2020. The questions for the two surveys were similar except that the second survey included additional questions related to the COVID-19 pandemic situation. The response rates were respectively 34\% (sample \#1) and 57\% (sample \#2). Responses from participants were saved in Excel and SPSS.

As shown in Table 1, the repartition of gender among the two samples is similar, with a greater proportion of men (49\% and $46 \%$ for men and $32 \%$ and $26 \%$ for women). The majority of respondents for each sample are employed full-time $(86 \%$ and $75 \%$ respectively), while $9 \%$ are full-time in school. However, the second sample shows a lower full-time employment rate and a higher part-time employment rate than the first sample. This could be explained by the current COVID-19 pandemic situation. Moreover, income between $\$ 40,000$ and $\$ 59,999$ accounted for $48 \%$ and $45 \%$ of each sample. A vast majority of students of the first sample found a job within six months $(81 \%)$, while it was lower for the second sample $(66 \%)$. Again, this difference could be explained by the COVID-19 pandemic situation. The vast majority of graduates had their first job in the private sector $(72 \%$ and $65 \%$ ) such as finance, insurance, banking, real estate, and tourism. The public sector accounted for the second most important industry (12\% and 6\%). Finally, students graduated in greater proportion from the discipline of marketing/entrepreneurship (33\% and $28 \%)$, then finance (24\% and $26 \%$ ), and finally, accounting (20\% and $22 \%)$. 
Table 1. Demographic characteristics of the study participants $(n=249 \& n=85)$

\begin{tabular}{|c|c|c|}
\hline & Frequency & Percentage \\
\hline \multicolumn{3}{|l|}{ Gender } \\
\hline Male & $121 / 39$ & $49 \% / 46 \%$ \\
\hline Female & $80 / 22$ & $32 \% / 26 \%$ \\
\hline Other & $48 / 24$ & $19 \% / 28 \%$ \\
\hline \multicolumn{3}{|l|}{ Employment status } \\
\hline Not employed & $8 / 3$ & $3 \% / 4 \%$ \\
\hline Full-time in school & $22 / 8$ & $9 \% / 9 \%$ \\
\hline Employed full-time & $213 / 64$ & $86 \% / 75 \%$ \\
\hline Employed part-time & $5 / 5$ & $2 \% / 6 \%$ \\
\hline Other & $1 / 5$ & $0 \% / 6 \%$ \\
\hline \multicolumn{3}{|c|}{ Time to find the first job after graduation } \\
\hline $0-6$ months & $201 / 56$ & $81 \% / 66 \%$ \\
\hline 7-12 months & $18 / 11$ & $7 \% / 13 \%$ \\
\hline More than 12 months & $6 / 2$ & $3 \% / 2 \%$ \\
\hline Other/NA & $23 / 16$ & $9 \% / 19 \%$ \\
\hline \multicolumn{3}{|l|}{ Income (before tax) } \\
\hline Less than $\$ 20,000$ & $11 / 8$ & $4 \% / 9 \%$ \\
\hline$\$ 20,000$ to $\$ 39,999$ & $25 / 14$ & $10 \% / 16 \%$ \\
\hline$\$ 40,000$ to $\$ 59,999$ & $120 / 38$ & $48 \% / 45 \%$ \\
\hline$\$ 60,000$ to $\$ 79,999$ & $37 / 12$ & $15 \% / 14 \%$ \\
\hline$\$ 80,000$ to $\$ 99,9999$ & $16 / 3$ & $6 \% / 4 \%$ \\
\hline$\$ 100,000$ and more & $19 / 1$ & $8 \% / 1 \%$ \\
\hline Other & $20 / 9$ & $8 \% / 11$ \\
\hline \multicolumn{3}{|l|}{ Industry Sector } \\
\hline $\begin{array}{l}\text { Service Sector } \\
\text { (banking, finance, } \\
\text { insurance, etc.) }\end{array}$ & $180 / 55$ & $72 \% / 65 \%$ \\
\hline $\begin{array}{l}\text { Public Sector (health } \\
\text { education, gov.) }\end{array}$ & $30 / 5$ & $12 \% / 6 \%$ \\
\hline IT & $11 / 6$ & $4 \% / 7 \%$ \\
\hline Manufacturing & $9 / 4$ & $4 \% / 5 \%$ \\
\hline Consulting & $5 / 3$ & $2 \% 3 \%$ \\
\hline Construction & $2 / 1$ & $1 \% / 1 \%$ \\
\hline $\begin{array}{l}\text { Not applicable (not } \\
\text { working or studying) }\end{array}$ & $12 / 11$ & $5 \% / 13 \%$ \\
\hline \multicolumn{3}{|l|}{ Discipline* } \\
\hline $\begin{array}{l}\text { Marketing/ } \\
\text { Enterpreneurship }\end{array}$ & $81 / 24$ & $33 \% / 28 \%$ \\
\hline Finance & $59 / 22$ & $24 \% / 26 \%$ \\
\hline Accounting & $49 / 19$ & $20 \% / 22 \%$ \\
\hline Global Management & $34 / 13$ & $14 \% / 15 \%$ \\
\hline International Business & $26 / 7$ & $10 \% / 8 \%$ \\
\hline Other & $3 / 1$ & $1 \% / 1 \%$ \\
\hline
\end{tabular}

*The cumulative score is over 100 percent as students can graduate from more than one discipline.

Lastly, the first sample consisted of students who graduated from 2016 to 2019 . The distribution of the cohorts was greater for the most recent years $(42 \%$,
$29 \%, 13 \%, 16 \%)$. To test for potential bias between the difference in importance perceptions of IT skills over time, a samples t-test was performed between each graduating cohort. No significant differences were found.

\subsection{Data collection questionnaire}

The questionnaire consisted of four parts. The first section was about the respondent's current status regarding employment (employment status, salary, industry, location). The second section contained questions on the challenges with the respondent's first job after graduation while the third section was about the skills and competencies related to their first job. Finally, the last section was about the demographics of the respondents.

More specifically, the second section asked about the time it took to find the respondent's first job after graduation. Also, using a 7-point Likert scale from $1=$ not at all to $7=$ very much, the respondents were asked the extent to which their first full-time job was related to their field of study. In the second sample, this section also included questions related to the COVID-19 pandemic, i.e. on a 7-point Likert scale (not at all to very much), the respondents were asked the extent to which the COVID-19 pandemic has (1) increased the job search behavior, (2) influenced accepting a lower salary, (3) influenced the consideration in applying to graduate school, (4) influenced in considering shifting the area of work to a more promising area, and (5) influenced in considering acquiring new digital/IT skills.

Finally, the third section looked at the skills and competencies related to their job. Using a 7-point Likert scale, students were asked to rate each skill on how essential they were to their job (not essential to absolutely essential) and if they were confident in applying the competency/skill on a day-to-day basis (not confident to very confident). The non-IT skills were: collaboration, problem-solving, communication, leadership, career management, emotional intelligence, conflict management, ethical behavior, stress management, and global/intellectual fluency. The IT skills were: ERP systems, data analytics and tools (SAS, $\mathrm{R}$, SPSS), and business applications of artificial intelligence (AI).

\subsection{Data analysis}

Hypotheses \#1 (IT vs non-IT skills) and \#3 (importance of IT skills because of the COVID-19 pandemic) were analyzed according to descriptive statistics (i.e., mean and standard deviation). To test for the second hypothesis, a paired sample t-test was conducted to compare the differences between the skills 
perceived as essential to perform the respondent's first job before and during the COVID-19 pandemic. The data analyses were executed using IBM SPSS Statistics 24.0. Finally, the last hypothesis (impact of the COVID19 on business graduates' career decisions), was tested with mixed methods. First, the data were analyzed according to descriptive statistics (i.e., mean and standard deviation) as well as a paired sample t-test for the question related to the extent to which the job after graduation was related to the respondent's field of study.

Table 2. Descriptive statistics of skills before and during the COVID-19 pandemic

\begin{tabular}{|c|c|c|c|c|c|c|}
\hline \multirow[t]{2}{*}{ Skills } & \multicolumn{2}{|c|}{$\begin{array}{c}\text { Before } \\
\text { COVID-19 }\end{array}$} & \multicolumn{2}{|c|}{$\begin{array}{c}\text { During } \\
\text { COVID-19 }\end{array}$} & \multirow[t]{2}{*}{$\begin{array}{c}\text { t- } \\
\text { value }\end{array}$} & \multirow[t]{2}{*}{$\begin{array}{c}P \\
\text { value }\end{array}$} \\
\hline & $\mathbf{M}$ & SD & M & SD & & \\
\hline \multicolumn{7}{|c|}{ Non-IT Skills } \\
\hline Comm. & 5.83 & 2.22 & 6.29 & 0.97 & -2.64 & $* *$ \\
\hline $\begin{array}{l}\text { Ethical } \\
\text { behavior }\end{array}$ & 5.78 & 2.27 & 6.38 & 1.00 & -3.34 & $* *$ \\
\hline $\begin{array}{l}\text { Problem } \\
\text { solving }\end{array}$ & 5.51 & 2.23 & 6.04 & 1.10 & -2.84 & $* *$ \\
\hline Collabo. & 5.50 & 2.29 & 6.15 & 1.22 & -3.30 & $* *$ \\
\hline $\begin{array}{l}\text { Stress } \\
\text { mgmt. }\end{array}$ & 5.25 & 2.42 & 5.79 & 1.24 & -2.66 & $* *$ \\
\hline $\begin{array}{l}\text { Emotional } \\
\text { intel. }\end{array}$ & 5.01 & 2.33 & 5.49 & 1.40 & -2.03 & $* *$ \\
\hline $\begin{array}{l}\text { Conflict } \\
\text { mgmt.. }\end{array}$ & 4.77 & 2.40 & 5.31 & 1.56 & -2.41 & $* *$ \\
\hline $\begin{array}{l}\text { Leader. } \\
\text { mgmt.. }\end{array}$ & 4.73 & 2.18 & 4.99 & 1.65 & -1.19 & n.s. \\
\hline $\begin{array}{l}\text { Career } \\
\text { mgmt.. }\end{array}$ & 4.26 & 2.28 & 4.71 & 1.73 & -1.92 & $*$ \\
\hline $\begin{array}{l}\text { Global/ } \\
\text { Intell. } \\
\text { fluency }\end{array}$ & 4.08 & 2.31 & 4.71 & 1.54 & -2.87 & $* *$ \\
\hline \multicolumn{7}{|c|}{ IT skills } \\
\hline $\begin{array}{l}\text { ERP } \\
\text { systems }\end{array}$ & 3.03 & 1.89 & 3.37 & 1.85 & -1.43 & n.s. \\
\hline $\begin{array}{l}\text { Data } \\
\text { analytics }\end{array}$ & 2.48 & 1.77 & 2.93 & 1.88 & -1.98 & $* *$ \\
\hline $\begin{array}{l}\text { App. of } \\
\text { AI }\end{array}$ & 2.41 & 1.65 & 2.79 & 1.85 & -1.72 & $*$ \\
\hline
\end{tabular}

\section{Findings}

\subsection{The importance of IT and non-IT skills for business graduates}

Descriptive statistics shown in Table 2 provide support for H1. Non-IT skills were perceived by business graduates as more essential for their first job for both before and during the COVID-19 pandemic. More specifically, communication ( 5.83 and 6.29), ethical behavior (5.78 and 6.38), problem-solving (5.51 and 6.04), and collaboration (5.50 and 6.15) were the top skills perceived as essential while the three IT skills were rated as the least essential (between 2.41 and 3.37).

For the second hypothesis, the results, as shown in Table 2, indicate partial support for H2. More specifically, all non-IT skills, except for the leadership management skill, were rated as different between the two periods with communication $(\mathrm{t}[320]=-2.64, \mathrm{p}<$ $0.05 ; \mathrm{M}_{\text {before }}=5.83, \mathrm{SD}=2.22 ; \mathrm{M}_{\text {during }}=6.29, \mathrm{SD}=$ 0.97), ethical behavior ( $\mathrm{t}[312]=-3.33, \mathrm{p}<0.05$; $\mathrm{M}_{\text {before }}$ $\left.=5.78, \mathrm{SD}=2.27 ; \mathrm{M}_{\text {during }}=6.38, \mathrm{SD}=1.00\right)$, problem solving $\left(\mathrm{t}[291]=-2.84, \mathrm{p}<0.05 ; \mathrm{M}_{\text {before }}=5.51, \mathrm{SD}=\right.$ $\left.2.23 ; \mathrm{M}_{\text {during }}=6.04, \mathrm{SD}=1.10\right)$, collaboration $(\mathrm{t}[272]=$ $-3.30, \mathrm{p}<0.05 ; \mathrm{M}_{\text {before }}=5.50, \mathrm{SD}=2.29 ; \mathrm{M}_{\text {during }}=6.15$, $\mathrm{SD}=1.22)$, stress management $(\mathrm{t}[283]=-2.66, \mathrm{p}<0.05$; $\left.\mathrm{M}_{\text {before }}=5.25, \mathrm{SD}=2.42 ; \mathrm{M}_{\text {during }}=5.79, \mathrm{SD}=1.24\right)$, emotional intelligence $\left(\mathrm{t}[246]=-2.03, \mathrm{p}<0.05 ; \mathrm{M}_{\text {before }}\right.$ $\left.=5.01, \mathrm{SD}=2.33 ; \mathrm{M}_{\text {during }}=5.49, \mathrm{SD}=1.40\right)$, conflict management $\left(\mathrm{t}[225]=-2.41, \mathrm{p}<0.05 ; \mathrm{M}_{\text {before }}=4.77, \mathrm{SD}\right.$ $\left.=2.4 ; \mathrm{M}_{\text {during }}=5.31, \mathrm{SD}=1.56\right)$, and global/intellectual fluency $\left(\mathrm{t}[220]=-2.87, \mathrm{p}<0.05 ; \mathrm{M}_{\text {before }}=4.08, \mathrm{SD}=\right.$ $\left.2.31 ; \mathrm{M}_{\text {during }}=4.71, \mathrm{SD}=1.54\right)$ as significantly different while career management $\left(\mathrm{t}[191]=-1.92, \mathrm{p}<0.1 ; \mathrm{M}_{\text {before }}\right.$ $\left.=4.26, \mathrm{SD}=2.28 ; \mathrm{M}_{\text {during }}=4.71, \mathrm{SD}=1.73\right)$ as marginally different $(\mathrm{p}<0.1)$.

Regarding the IT skills, the results provide also partial support for $\mathrm{H} 2$. Data analytics $(\mathrm{t}[154]=-1.98, \mathrm{p}$ $0.24 ; \mathrm{M}_{\text {before }}=2.48, \mathrm{SD}=1.77 ; \mathrm{M}_{\text {during }}=2.93, \mathrm{SD}=1.88$ and applications of $\mathrm{AI}\left(\mathrm{t}[133]=-1.72, \mathrm{p} \quad 0.08 ; \mathrm{M}_{\text {before }}=\right.$ $2.41, \mathrm{SD}=1.65 ; \mathrm{M}_{\text {during }}=2.79, \mathrm{SD}=1.85$ ) were rate as significantly different between before and during the COVID-19 pandemic while for the ERP skill $(\mathrm{t}[148]=$ $-1.43, \mathrm{p} 0.16 ; \mathrm{M}_{\text {before }}=3.03, \mathrm{SD}=1.89 ; \mathrm{M}_{\text {during }}=3.37$, $\mathrm{SD}=1.85$ ), it was not significantly different.

Finally, H3 was supported, showing that the IT skills had a greater impact on the difference in the importance of skills before and during the COVID-19 pandemic. Precisely, the data analytics and the business applications of AI skills increased respectively by $18 \%$ (2.48 to 2.93 ) and $16 \%$ (2.41 and 2.79), gaining more reputation than other skills. The non-IT skills increased between $5 \%$ and $15 \%$ while the last IT skill (ERP systems) increased by $11 \%$.

\section{Table 3. Descriptive statistics of the impact of the COVID-19 pandemic on various employment considerations}

\begin{tabular}{|l|c|c|}
\hline Item & Mean & SD \\
\hline Acquire IT skills & 4.01 & 1.83 \\
\hline Job search behavior & 3.92 & 1.97 \\
\hline Graduate school & 3.71 & 2.17 \\
\hline Shift work area & 3.06 & 1.97 \\
\hline Accept lower salary & 3.02 & 1.89 \\
\hline
\end{tabular}




\subsection{Impact of the COVID-19 pandemic on business graduates}

As shown in Table 3, the results of the descriptive statics for the last hypothesis $(\mathrm{H} 4)$ show that considering acquiring new digital/IT skills was the most important factor impacted by the COVID-19 pandemic $(\mathrm{M}=4.01$, $\mathrm{SD}=1.83$ ). Meanwhile, the least impacted factor was accepting a job at a lower salary $(\mathrm{M}=3.02$ and $\mathrm{SD}=$ 1.82). Concerning the increase in job search behavior $(\mathrm{M}=3.92, \mathrm{SD}=1.97)$ it was slightly more important than considering applying to graduate school $(\mathrm{M}=3.71$, $\mathrm{S}=2.17$ ), but more important than considering shifting to a different area of work $(\mathrm{M}=3.06, \mathrm{SD}=1.97)$.

Additionally, when comparing the difference in the rated association the respondent's job and the field of study (before and during the COVID-19 pandemic), the results indicate no significant difference $(\mathrm{t}[298]=-1.27$, $\mathrm{p}=0.2 ; \mathrm{M}_{\text {before }}=4.79, \mathrm{SD}=2.00 ; \mathrm{M}_{\text {during }}=5.14, \mathrm{SD}=$ 1.98), providing partial support for $\mathrm{H} 4$.

\section{Discussion and implications}

\subsection{Discussion}

The current study aimed to identify (1) the perceived importance of IT and non-IT skills of business graduates, (2) the impact of the COVID-19 pandemic on these skills for students who graduated before and during the COVID-19 pandemic, and (3) the impact of the COVID-19 pandemic on graduates' careers decisions and outcomes. This study also sought to advance practice in ways that help students and businesses understand the impact of the COVID-19 pandemic while advancing employability theory that generalizes beyond the crisis.

By using a survey of business students who graduated before and during the COVID-19 pandemic, it was found that communication, problem-solving, ethical behavior, and collaboration were the top four skills essential for business students. These results are consistent with earlier studies. For instance, it was found that non-IT skills such as listening, interpersonal, and verbal communication were important for graduates' employability [45] and soft skills are important for accounting students' employability [8]. Employers prioritized graduates who possess skills such as problem solving and communication [36]. Communication, listening, and interpersonal skills were also recognized by managers as highly desired skills for business graduates in the banking industry [31] and graduates of management sciences [29]. IT skills such as computing and analytical skills were found to be important for business graduates in Kuwait [34]. However, this study shows that non-IT skills were perceived as more essential than IT skills for business students. This may be explained partially by the fact that (1) only non-IS business graduates were considered in the sample and (2) business graduates in their first job may not need advanced IT skills in entry-level jobs where they are expected to have basic IT skills [31].

The data used in this study offer some preliminary evidence that the introduction of the COVID-19 pandemic has increased the perceived importance of IT and non-IT skills for business students entering the working force. Students who graduated during the COVID-19 pandemic placed more importance on all the non-IT skills except for leadership and career management. For IT skills, it was found that students who graduated during the COVID-19 pandemic placed more importance on data analytics and business applications of AI as essential skills for their job. Similar studies have found differences in skills between before and after the COVID-19 pandemic [37]. Furthermore, the two IT skills previously stated gained more perceived importance than other non-IT skills by students who graduated during the COVID-19 pandemic. This is in line with the paradigm shift that IT skills play in current and future training to support the digital transformation, which can be accentuated with turbulent contexts such as the COVID-19 pandemic [8].

Finally, business students who graduated during the COVID-19 pandemic have been impacted by the situation for their career decisions and outcomes. More specifically, these students are looking to acquire new IT skills and have increased their job search behavior. The COVID-19 pandemic can be seen as a career shock for business graduates $[9,46]$. Indeed, the shock created by the COVID-19 pandemic was linked to greater socioeconomic disparities in higher education [9]. How individuals deal with career shocks can vary and developing career competencies is likely to help them better cope with negative career shocks by becoming more engaged and employable [47]. Furthermore, similar to prior studies on the impacts of negative career shocks, the negative career shock brought about by the COVID-19 pandemic might also bring opportunities for career development and skill upgrades, especially for the use of information technology and digital technology [48, 49]. Finally, the COVID-19 pandemic has been shown to influence job search behavior, i.e. job applications [43], which supports the findings of this study.

\subsection{Implications}

This study has implications for both educational institutions and students. First, universities may be judged by their performance in preparing graduates with 
skills that enable them to work effectively in today's complex work environment. Thus, the evaluation of skills essential post-graduation to perform a job can contribute to the improvement of a curriculum. The analysis performed in this study can offer a first step in the improvement of a business curriculum and evaluate the value of the education gained.

This study can also provide valuable feedback on graduates.' experiences in the workplace and how higher education impacted the students' experience. Graduates who have completed a program are often able to evaluate its effectiveness and make comments regarding content areas to be included in the curriculum once they are in the workforce. Thus, this might assist higher education institutions in enhancing their curricula and professional skills taught to match the jobmarket conditions and embed necessary skills in their course [16].

Second, for students, this study might help them in understanding the importance of soft skills for business degrees and selecting universities that offer those skills. Students may not have a clear understanding of job skills needed to transition from the university to working life and thus, fail to recognize the different types of skills required in different types of jobs or industries [50]. In this regard, this study makes business graduates understand that developing collaboration, ethical behavior, problem-solving, and communication skills are important throughout their education, which can be done outside of traditional courses such as case competitions, internships, join student-industry projects, and career development activities. This can maximize their potential for desired employability and better position themselves.

Finally, for research, the findings of this study are expected to add to the small but growing body of empirical studies on the impact of the COVID-19 pandemic in higher education and more specifically on business students. This study offers also implications for job search theory and for directing future research, especially given that context has not played a central role in the job search literature [43]. The COVID-19 pandemic may influence the type of jobs for which applicants apply in the future [8]. Finally, this study will contribute to the literature on career shocks by showing some factors that can influence how people cope with negative career shocks [46].

\section{Limitations and direction for future research}

Although the current study contributes to the literature on graduate employability and business management education, some limitations should be addressed as well as future research. First, any inferences from this study's findings should be made with caution. This study does not claim that the business student's surveyed completely represent the views of all business students. The findings, however, should not be overlooked since they are generated from a rich sample of business students who are knowledgeable of the skills necessary for a position in the business field.

Second, the first sample (before the COVID-19 pandemic) contains respondents who graduated from multiple years (2016-2019). Skills, especially IT skills could have changed over time as well as the recall of their first job. Further research could split the first sample in each year as well as looking at the sample from a discipline and industry perspectives to uncover different findings. For instance, research has been done on accounting students' skills and results could be expected to be different based on the discipline. Thus, the type of skills may vary depending on the type of industry sector or the kind of professional [26].

Third, for the third and fourth hypotheses, with the results of the study being restricted to descriptive statistics, this limits the degree to which the findings can be generalized. Furthermore, for the last hypothesis, only acquiring IT skills were measured. It would be interesting to be more specific about which skills (IT and non-IT) and which IT skills (programming, analytics, etc.) students would likely acquire because of the COVID-19 pandemic.

Fourth, the IT skills that were selected in the data collection were restricted to three areas: ERP, analytics, and AI. Given the novelty in analytics and AI, the results may not reflect the real importance of those skills for students who graduated earlier. Additionally, other IT skills could be included in future research such as Excel programming, and VBA. Finally, other control variables such as gender, household income, and ethnicity have been shown to influence the digital barriers in distance education, which could also influence the need to acquire new IT skills [41].

Finally, the data was collected while the outbreak was still in effect, capturing only a portion of the impact of the COVID-19 pandemic. Therefore, follow-up studies are needed to identify graduate employability and the skills essentials to enter the working force in the COVID-19 pandemic era. Thus, future research needs to look at how the skills perceived as being essential shortly during the pandemic's onset continue as the pandemic evolves and after the pandemic. Indeed, a career shock such as the COVID-19 pandemic can have different impacts in the short-term versus the long-term and for different career stages [46]. It can also influence the type of jobs to which applicants apply.

With the data set available, further research is conceivable by analyzing more questions. For example, it may be possible to look at the difference between the 
perceived importance of the skills versus the perceived confidence in having those skills. Thus, future studies can be undertaken to investigate gaps in the skills and abilities of business graduates. Another important avenue for future research would be to look at the link between students who are confident with certain skills and the time to find a job. It could be expected that some skills may help to reduce the time needed to find a job.

Finally, further examination may be conducted to identify the employability skills of business graduates required by various industries and from an employer's point of view, as well as the impact of the COVID-19 pandemic longitudinally over different graduating cohorts and socioeconomic factors $[9,51]$. For example, lower-income students have been further impacted by the COVID-19 pandemic compared to their more affluent peers and the impact on Honors students' academic outcomes is smaller than the impact on nonHonors students [9]. Finally, the perspective of the employers should also be considered when researching the temporal shift in employability over time and the impact of the COVID-19 job requirements. TO understand the skills needed by business graduates, the employers' needs should be considered [2, 13, 35]. However, given the relatively small sample size, additional data would need to be collected to include control variables, employer's perspective, and longitudinal data.

\section{Conclusion}

This study provides a first analysis of the effects of the COVID-19 pandemic on business graduates and the importance of IT skills and non-IT skills when entering the working force. To study these effects, business students from a small liberal arts university were surveyed and quantitative evidence showing the effects of the pandemic on students' careers outcomes and decisions as well as the importance of various IT and non-IT skills were presented. For example, it was found that non-IT skills are more essential than IT skills for business students in non-IS programs and that the COVID-19 pandemic has increased the importance of non-IT skills such as communication, collaboration, and ethical behavior, and IT skills in data analytics and business application of AI. Expanding upon these results, it was found that because of the COVID-19 pandemic, students are considering acquiring new IT skills and increased their job search behavior. The results of this study may inform the development of future business graduates' skills to better prepare them for the workforce, especially during a challenging time such as the COVID-19 pandemic.

\section{References}

[1] Sumanasiri, E.G.T., M.S.A. Yajid, and A. Khatibi, "Conceptualizing Learning and Employability 'Learning and Employability Framework", Journal of Education and Learning 4(2), 2015, pp. 53-63.

[2] Andrews, J., and H. Higson, "Graduate Employability, 'Soft Skills' Versus 'Hard' Business Knowledge: A European Study", Higher Education in Europe 33(4), 2008, pp. 411422.

[3] Dacre Pool, L., P. Qualter, and P. J. Sewell, "Exploring the factor structure of the CareerEDGE employability development profile", Education + Training 56(4), 2014, pp. 303-313.

[4] Gill, R.J., "Graduate employability skills through online internships and projects during the COVID-19 Pandemic: An Australian example.", Journal of Teaching and Learning for Graduate Employability 11(1), 2020, pp. 146-158.

[5] Singh, H., and S. Verma, "Evolution of IS Competencies due to Mandatory Telework on Organizational scale - A Work-Systems Approach", Proceedings of the 54th Hawaii International Conference on System Sciences, (2021), 57895798.

[6] Pan, G., and P.-S. Seow, "Preparing accounting graduates for digital revolution: A critical review of information technology competencies and skills development", Journal of Education for Business 91(3), 2016, pp. 166-175.

[7] Murawski, M., and M. Bick, "Digital competences of the workforce - a research topic?", Business Process Management Journal 23(3), 2017, pp. 721-734.

[8] Alhawsawi, M., "Soft Accounting Skills between Employers' Expectations and Students' Reality after COVID19 Pandemic", Australian Academy of Accounting and Finance Review 5(2), 2020, pp. 69-76.

[9] Aucejo, E.M., J. French, M.P. Ugalde Araya, and B. Zafar, "The impact of COVID-19 on student experiences and expectations: Evidence from a survey", Journal of Public Economics 191, 2020, pp. 104271.

[10] Kamaruddin, M.I.H., A. Ahmad, M.A. Husain, and S.N. Abd Hamid, "Graduate employability post-COVID-19: the case of a Malaysian public university", Higher Education, Skills and Work-Based Learning ahead-of-print(ahead-ofprint), 2020.

[11] Gibbs, S., G. Steel, and A. Kuiper, "Expectations of Competency: The Mismatch between Employers' and Graduates' Views of End-User Computing Skills Requirements in the Workplace", Journal of Information Technology Education:Research 10, 2011, pp. 371-382.

[12] Campbell, T.A., "A phenomenological study of business graduates' employment experiences in the changing economy", Journal for Labour Market Research 52(1), 2018, pp. $1-10$.

[13] Jewell, P., J. Reading, M. Clarke, and L. Kippist, "Information skills for business acumen and employability: A competitive advantage for graduates in Western Sydney", Journal of Education for Business 95(2), 2020, pp. 88-105.

[14] Kaminski, K., J. Switzer, and G. Gloeckner, "Workforce readiness: A study of university students' fluency with information technology", Computers \& Education 53(2), 2009, pp. 228-233. 
[15] Legier, J., B. Woodward, and N.L. Martin, "Reassessing the Skills Required of Graduates of an Information Systems Program: An Updated Analysis", Information Systems Education Journal 11(3), 2013, pp. 79-89.

[16] Buarki, H., M. Hepworth, and I. Murray, "ICT skills and employability needs at the LIS programme Kuwait: a literature review", New Library World 112(11/12), 2011, pp. 499-512. [17] Ahmad, N., A. Obaidat, and R. Alqatamin, "Integrating Information Technology (IT) into Accounting Courses", International Journal of Business and Management 6(10), 2011, pp. 205-212.

[18] Dillon, T.W., and S.E. Kruck, "Identifying Employer Needs from Accounting Information Systems Programs", Journal of Information Systems Education 19(4), 2008, pp. 403-410.

[19] Sithole, S.T.M., "Information Technology Knowledge and Skills Accounting Graduates Need.", International Journal of Business and Social Science 6(8), 2015, pp. 47-52. [20] Spraakman, G., W. O'Grady, D. Askarany, and C. Akroyd, "Employers' Perceptions of Information Technology Competency Requirements for Management Accounting Graduates", Accounting Education 24(5), 2015, pp. 403-422. [21] Royle, J., and A. Laing, "The digital marketing skills gap: Developing a Digital Marketer Model for the communication industries", International Journal of Information Management 34(2), 2014, pp. 65-73.

[22] Misra, R.K., and K. Khurana, "Employability Skills among Information Technology Professionals: A Literature Review", Procedia Computer Science 122, 2017, pp. 63-70. [23] Uğur, N.G., and A.H. Turan, "Critical professional skills of MIS graduates: Practitioner vs. Academician perspectives", Journal of Education for Business 94(4), 2019, pp. 251-258. [24] Boyle, T., and S. Strong, "Skill Requirements of ERP Graduates", Journal of Information Systems Education 17(4), 2006, pp. 403-412.

[25] Clayton, P.R., and J. Clopton, "Business curriculum redesign: Integrating data analytics", Journal of Education for Business 94(1), 2019, pp. 57-63.

[26] Periáñez-Cañadillas, I., J. Charterina, and J. PandoGarcía, "Assessing the relevance of digital competences on business graduates' suitability for a job", Industrial and Commercial Training 51(3), 2019, pp. 139-151.

[27] Jackling, B., and R. Natoli, "Employability skills of international accounting graduates: Internship providers' perspectives", Education + Training 57(7), 2015, pp. 757773.

[28] Jackson, D., and E. Chapman, "Non-technical competencies in undergraduate business degree programs: Australian and UK perspectives", Studies in Higher Education 37(5), 2012, pp. 541-567.

[29] McMurray, S., M. Dutton, R. McQuaid, and A. Richard, "Employer demands from business graduates", Education + Training 58(1), 2016, pp. 112-132.

[30] Crews, T., and M. McCannon, "Comparison of Communication Skills Needed by Information Systems Undergraduates and Graduates as Perceived by Information Systems Professionals", Journal of Information Systems Education 11(3), 2000, pp. 151-156.

[31] Abbasi, F.K., A. Ali, and N. Bibi, "Analysis of skill gap for business graduates: managerial perspective from banking industry", Education + Training 60(4), 2018, pp. 354-367.
[32] Wilkerson, J., "An Alumni Assessment of MIS Related Job Skill Importance and Skill Gaps", Journal of Information Systems Education 23(1), 2012, pp. 188-197.

[33] Aasheim, C., L. Li, and S. Williams, "Knowledge and Skill Requirements for Entry-Level Information Technology Workers: A Comparison of Industry and Academia", Journal of Information Systems Education 20(3), 2009, pp. 349-356.

[34] Al-Mutairi, A.N., K. Naser, and M. Saeid, "Employability Factors of Business Graduates in Kuwait: Evidence from An Emerging Country", International Journal of Business and Management 9(10), 2014, pp. 49-61.

[35] Baird, A.M., and S. Parayitam, "Employers' ratings of importance of skills and competencies college graduates need to get hired: Evidence from the New England region of USA", Education + Training 61(5), 2019, pp. 622-634.

[36] Oraison, H., L. Konjarski, and S. Howe, "Does university prepare students for employment? Alignment between graduate attributes, accreditation requirements and industry employability criteria", Journal of Teaching and Learning for Graduate Employability 10, 2019, pp. 173.

[37] Sato, S., T.-A. Kang, E. Daigo, H. Matsuoka, and M. Harada, "Graduate employability and higher education's contributions to human resource development in sport business before and after COVID-19”, Journal of Hospitality, Leisure, Sport \& Tourism Education 28, 2021, pp. 100306.

[38] Liguori, E., and C. Winkler, "From Offline to Online: Challenges and Opportunities for Entrepreneurship Education Following the COVID-19 Pandemic", Entrepreneurship Education and Pedagogy 3(4), 2020, pp. 346-351.

[39] Ratten, V., and P. Jones, "Covid-19 and entrepreneurship education: Implications for advancing research and practice", The International Journal of Management Education 19(1), 2021, pp. 100432.

[40] Alvarado-Bravo, N., F. Aldana-Trejo, A. Torres-Quiroz, et al., "The Context of the Covid-19 Pandemic and its Effect on the Self-Perception of Professional Competences by University Students of Business Administration", Advances in Science Technology and Engineering Systems Journal 6(2), 2021, pp. 665-670.

[41] Krishnamurthy, S., "The future of business education: A commentary in the shadow of the Covid-19 pandemic", Journal of Business Research 117, 2020, pp. 1-5.

[42] McFarland, L.A., S. Reeves, W.B. Porr, and R.E. Ployhart, "Impact of the COVID-19 pandemic on job search behavior: An event transition perspective", Journal of Applied Psychology 105(11), 2020, pp. 1207-1217.

[43] Gan, I., and R. Sun, "Digital Divide and Digital Barriers in Distance Education during COVID-19", Proceedings of the 54th Hawaii International Conference on System Sciences 2021, (2021), 4838-4847.

[44] Anderson, V., "A digital pedagogy pivot: re-thinking higher education practice from an HRD perspective", Human Resource Development International 23(4), 2020, pp. 452467.

[45] Finch, D.J., L.K. Hamilton, R. Baldwin, and M. Zehner, "An exploratory study of factors affecting undergraduate employability", Education + Training 55(7), 2013, pp. 681704.

[46] Akkermans, J., J. Richardson, and M.L. Kraimer, "The Covid-19 crisis as a career shock: Implications for careers and 
vocational behavior", Journal of Vocational Behavior 119, 2020 , pp. 103434.

[47] Blokker, R., J. Akkermans, M. Tims, P. Jansen, and S. Khapova, "Building a sustainable start: The role of career competencies, career success, and career shocks in young professionals' employability", Journal of Vocational Behavior 112, 2019, pp. 172-184.

[48] Akkermans, J., S.E. Seibert, and S.T. Mol, "Tales of the unexpected: Integrating career shocks in the contemporary careers literature", SA Journal of Industrial Psychology 44(0), 2018, pp. 10.

[49] Richardson, J., and S. McKenna, "An exploration of career sustainability in and after professional sport", Journal of Vocational Behavior 117, 2020, pp. 103314.

[50] Lim, Y.-M., T.H. Lee, C.S. Yap, and C.C. Ling, "Employability skills, personal qualities, and early employment problems of entry-level auditors: Perspectives from employers, lecturers, auditors, and students", Journal of Education for Business 91(4), 2016, pp. 185-192.

[51] Jackson, D., "Modelling graduate skill transfer from university to the workplace", Journal of Education and Work 29(2), 2016, pp. 199-231. 